\title{
Ichthyobodo hippoglossi n. sp. (Kinetoplastea: Prokinetoplastida: Ichthyobodonidae fam. nov.), an ectoparasitic flagellate infecting farmed Atlantic halibut Hippoglossus hippoglossus
}

\author{
Trond E. Isaksen, Egil Karlsbakk*, Are Nylund \\ Department of Biology, University of Bergen, 5020 Bergen, Norway
}

\begin{abstract}
Diseased Atlantic halibut Hippoglossus hippoglossus juveniles from a hatchery in western Norway showed gill and skin infections with an Ichthyobodo species. Genus Ichthyobodo contains a single valid species, I. necator, a parasite originally described from the skin and fins of a salmonid fish in freshwater. Many studies have identified this species from other hosts, but recent molecular evidence suggests that many Ichthyobodo spp. occur in both fresh- and seawater. We redescribe I. necator from Atlantic salmon Salmo salar skin infections in Norway and compare the morphology of $I$. necator with the form from halibut. A scheme to standardise the measurements of Ichthyobodo cells is presented. Morphologically, the Ichthyobodo species from the skin and gills of halibut differs from I. necator from salmon skin by shape (in air dried stained smears), by a low number of variably sized kinetoplasts and by a long flagellar pocket. There is also a clear increase in the number of kinetoplasts in I. necator with increasing cell size (area), a pattern absent from Ichthyobodo sp. from halibut. The 2 forms are also clearly separated by their small subunit (ssu) rDNA sequences; alignments of partial ssu sequences showed $93.5 \%$ similarity. Consequently, Ichthyobodo sp. from halibut is considered a new species, and is named I. hippoglossi n. sp. Its closest relative is Ichthyobodo sp. IV from another marine fish, the Atlantic cod Gadus morhua. A family, Ichthyobodonidae fam. nov. in the order Prokinetoplastida Vickerman, 2004, is erected to encompass Ichthyobodo spp.
\end{abstract}

KEY WORDS: Ichthyobodo spp. · I. hippoglossi · I. necator · Halibut · Salmon · Parasite $\cdot$ Marine Flagellates $\cdot$ ssu rDNA $18 \mathrm{~s} \cdot$ Ichthyobodonidae $\cdot$ Characters

\section{INTRODUCTION}

In November 2003 and October 2004, increased mortality occurred among intensively reared Atlantic halibut Hippoglossus hippoglossus (L.) juveniles in a fish farm in western Norway. These mortalities occurred during weaning and were associated with co-infections of bacteria on the gills and flagellates on the skin and gills. The flagellates were identified as a species of the genus Ichthyobodo. Ichthyobodo sp. infections on farmed halibut have previously been reported from Scotland (Bruno \& Shields, in: Bruno 1992) and Norway (Rødseth 1995, Bergh et al. 2001).
Ichthyobodo spp. infections have been blamed for diseased conditions and mortalities among cultured fish worldwide (Robertson 1985, Lom \& Dyková 1992, Urawa et al. 1998). The genus comprises only one valid species, I. necator (Henneguy, 1883) (see Lom \& Dyková 1992). However, recent molecular studies have revealed that there are several species within the genus Ichthyobodo in both fresh- and seawater, and suggest that $I$. necator sensu Henneguy (1883) is a parasite infecting salmonids as well as sticklebacks in freshwater (Todal et al. 2004).

There are few morphological descriptions of Ichthyobodo parasites from the marine environment (Dia- 
mant 1987, Forsythe et al. 1991, Urawa et al. 1991, 1998), and no unambiguous characters have been identified that distinguish them from I. necator. A problem has obviously been the large variation exhibited by that species, which arose from the prevailing concept of one cosmopolitan species. From recent molecular studies (Todal et al. 2004, Callahan et al. 2005), it now appears clear that the different morphological studies on $I$. necator have dealt with several species. Hence our morphological conception of $I$. necator needs to be delimited to the species described by Henneguy $(1883,1884)$, a parasite on the skin of salmonid fry, and morphological characters must be sought that can differentiate new species detected by molecular methods (Todal et al. 2004). In the present study we examined ssu rDNA sequences of Ichthyobodo sp. from halibut and found them distinct from those of $I$. necator from salmonids. We then attempted to detect differences in morphological characters that would distinguish between them, preferably at the light microscopical level. The relationship of Ichthyobodo sp. from halibut to other Ichthyobodo spp. or strains was also examined using ssu rDNA sequences.

\section{MATERIALS AND METHODS}

Ichthyobodo sp. from skin and gills of weaned halibut fry ( 0.67 to $0.83 \mathrm{~g}$ ) from a hatchery in western Norway (Moldefjorden, Møre og Romsdal county) were examined. The hatchery produces halibut larvae in a land-based system (incubators, silos, fish tanks). The rearing water is taken from a depth of $238 \mathrm{~m}$, filtered $(60 \mu \mathrm{m})$ and ozonated before use.

Samples from juvenile halibut were taken by the farmers during the autumns of 2003 and 2004, and sent to the Fish Diseases laboratory at the Department of Biology, University of Bergen. The samples included air-dried scrapings from the body surface and gills (for light-microscopy), and whole halibut and gill samples preserved in $90 \%$ ethanol (for PCR) or fixed in a phosphate buffered Karnovsky (scanning electron microscopy, SEM).

Ichthyobodo necator samples were obtained in August 2000 from the skin of salmon parr, reared in a hatchery in Hordaland, W Norway. The material is the same as that designated Ichthyobodo sp. I and Ss1isolate by Todal et al. (2004). An additional ssu rDNA sequence from freshwater farmed Oncorhynchus mykiss from Osterøy, W Norway was also included (DQ414519). Stained smears of I. necator from salmon and Ichthyobodo n. sp. from halibut are deposited in the Zoological Museum University of Bergen (ZMBN 77813, voucher and ZMBN 77812, syntype, respectively).
Air dried smears were stained with Diff-Quick ${ }^{\mathrm{TM}}$ and the Ichthyobodo spp. cells studied at $1000 \times$ magnification in a Leitz Aristoplan microscope equipped with a digital camera (Olympus Camedia C-5050). The flagellates were measured on images using the software UTHSCSA ImageTool (2.00 alpha), but the original specimens were simultaneously examined in the microscope to verify details. Measurements were only taken when cells were either completely free or clearly attached (trophozoites), and most of the principal characters ('cytostome', nucleus and either axostyle or flagellar pocket) were clearly displayed. The extent of the flagellar pocket was measured only when it was clearly outlined as a bright area in the cell. The term 'cytostome' is used for a 'nose-like' protrusion of the cell at the border of the flagellar pocket, containing the end of the axostyle. This part of the cell corresponds to the attachment disc, which includes the cytostome according to Lom \& Dyková (1992). In the present study, this structure is defined as the anterior part of the cell and represents a starting point for the measurements. Measurements of the Ichthyobodo spp. cells were made as illustrated in Fig. 1. In addition, cell and nucleus area was measured. Locations of vacuoles and the number of flagellae were noted when visible. Flagellae were measured from the margin of the cell near the flagellar pocket; hence measurements represents the free part of flagellae and not their total length. The number of visible cytoplasmic basophilic granules (kinetoplasts) was counted. In addition, dimensions of small, large and 'typical' sized kinetoplasts were measured.

The measurements of Ichthyobodo spp. cells from halibut and salmon were compared using Student's $t$ test, following normality testing in Statistica ${ }^{\circledR}$. Correlations were examined with Spearman rank-order correlation coefficients $\left(R_{S}\right)$. Probabilities $(p)<0.05$ were considered significant.

DNA was extracted from the ethanol-conserved samples using a DNeasy tissue kit (Qiagen) for isolation of total DNA from animal tissues. DNA was eluted in $50 \mu \mathrm{l} \mathrm{AE} \mathrm{buffer} \mathrm{supplied} \mathrm{with} \mathrm{the} \mathrm{Qiagen} \mathrm{kit} \mathrm{and}$ stored at $-20^{\circ} \mathrm{C}$ before use in PCR. The PCR products were purified using a QIAquick PCR purification kit (Qiagen) and then sequenced using a BigDye terminator sequencing kit. The sequencing was performed using Primer BF9 (5'-GCTAACGCGAAGCTAATACA TGTAAGC-3') in addition to the primers described by Todal et al. (2004). The sequence data were assembled with the help of VeCTOR NTI software (InforMax), and GenBank searches were done with Blast (2.0). The VECTOR NTI Suite software package was used for multiple alignments of partial sequences. To perform pairwise comparisons between the different isolates, the multiple sequence alignment editor GENEDoc 

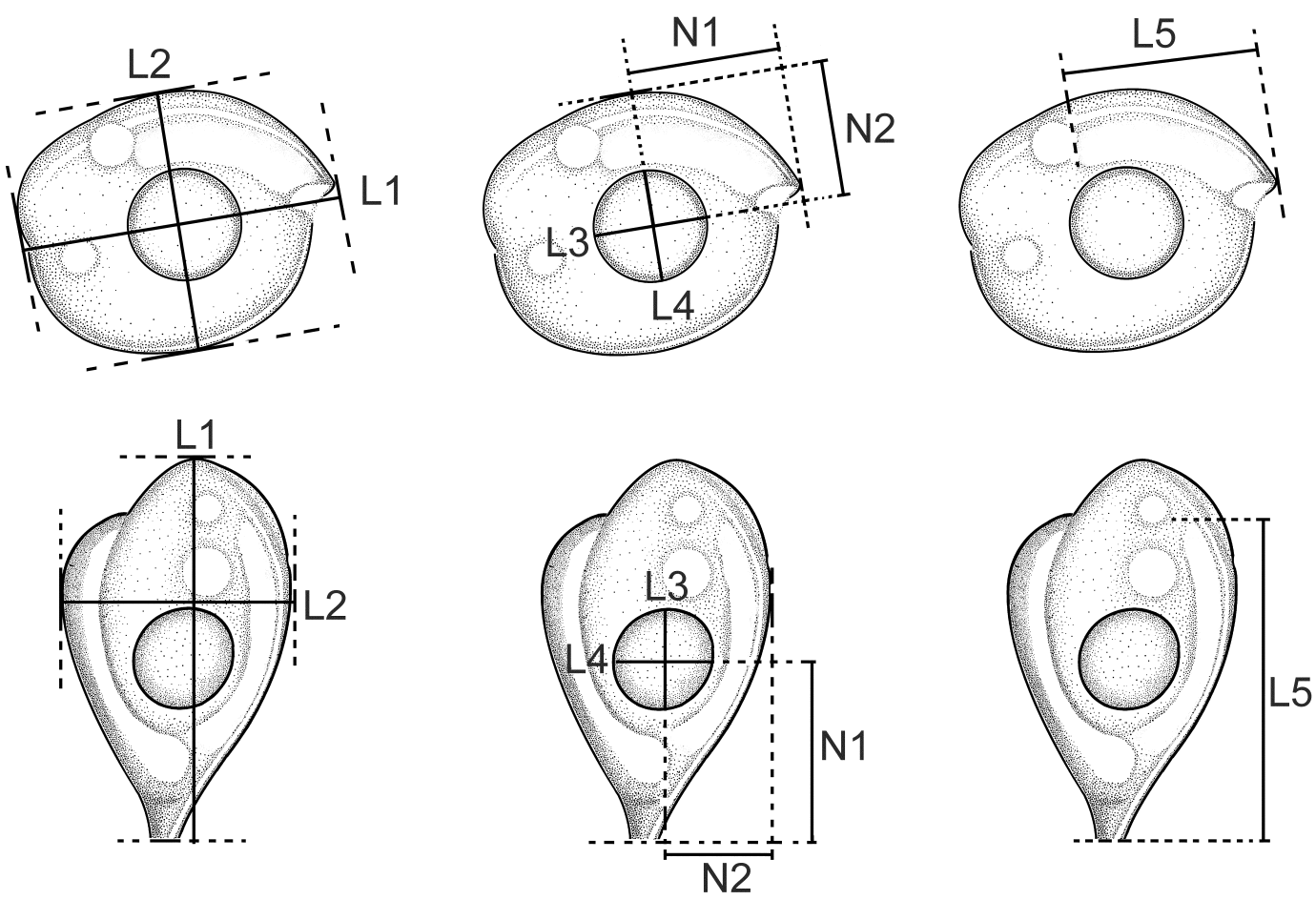

Fig. 1. Ichthyobodo spp. Measurements of cells. L1: Cell length measured from nose-like protrusion (cytostome) and along medial axis of cell; L2: width measured as maximum diameter at right angles to L1. L3, L4, L5 and N1, N2 measured parallel to L1 and $\mathrm{L} 2$ respectively

(available at www.psc.edu/biomed/genedoc) was used. Hypervariable or ambiguous regions were deleted from the alignment to ensure comparison of homologous positions. Phylogenetic analysis of the data sets were performed with PAUP* (4.0b10) (Swofford 2000) and TReEPuzzle (5.0), using the maximum likelihood method, with 1000 and 10000 replicates respectively. A general time reversible (GTR) model of nucleotide substitution with a 6 category gamma distribution (GTR $+\Gamma+\mathrm{I}$ ) was used following examination of the data with the programme Modeltest (Posada \& Crandall 1998). Phylogenetic trees were drawn using TreeView (Page 1996).

\section{RESULTS}

The flagellates were observed in 2 forms in the smears, either as free forms or as trophozoites attached to host cells. Both forms were observed in skin and gill smears from both halibut and salmon. The convex side of the cell is referred to as dorsal, the concave side containing the aperture of the flagellar pocket as ventral; hence, reference to right and left sides of the flagellate indicates a dorso-ventral view. The descriptions (below) refer to the morphology of cells in stained smears, unless otherwise indicated.

\section{Ichthyobodo sp. from halibut (Figs. 2 \& 3)}

Free form. In stained smears, the free form of the flagellate is rounded or oval (L1 > L2, in Table 1). Cells with both 2 and 4 flagellae occur. Quadriflagellate cells $(\mathrm{n}=9,12.4 \pm 0.7 \times 11.5 \pm 1.2 \mu \mathrm{m}[$ mean $\pm \mathrm{SD}])$ accounted for $36 \%$ of the examined cells; they are larger on average (not statistically significant, $p>0.05$ ) than biflagellate cells $(n=16,11.7 \pm 1.1 \times 11.0 \pm 1.1 \mu \mathrm{m})$. The free part of the flagellae is of unequal length; in our study the shorter measured 5.7 to 14.3 (mean 9.6) $\mu \mathrm{m}(\mathrm{n}=11)$, the longer 13.6 to $22.3(18.4) \mu \mathrm{m}(\mathrm{n}=16)$. The flagellae originate in a flagellar pocket, which appears as a bright area to the right of the nucleus and typically extends over more than half the longitudinal axis ('pocket index', $\mathrm{Pi}$ in Table 1). The pocket opens antero-ventrally, and continues into a longitudinal groove at or near the left cell margin. The nucleus is rounded and centrally located in the cell. In Diff-Quick ${ }^{\mathrm{TM}}$ stained smears, the nucleus shows as irregular eosinophilic chromatin on a pale background. A distinct basophilic endosome is usually evident. The area of the nucleus constitutes ca. $1 / 6$ th of the cell area (Table 1).

When clearly visible, the axostyle appears as a bent pale rod between the right margin and the flagellar pocket. The anterior end of the axostyle enters the cytostomal protrusion of the cell. 

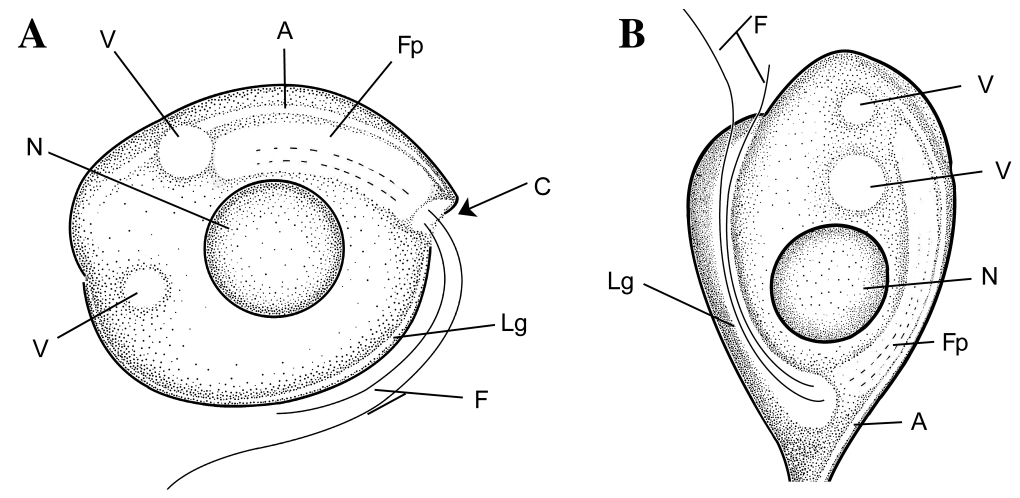

Fig. 2. Ichthyobodo sp. Characteristic structure of cells from halibut Hippoglossus hippoglossus, ventral view. Kinetoplasts not drawn. (A) Free form; (B) trophozoite. A: axostyle; C: cytostome; F: flagella; Fp: flagellar pocket; Lg: longitudinal groove; N: nucleus; V: vacuole
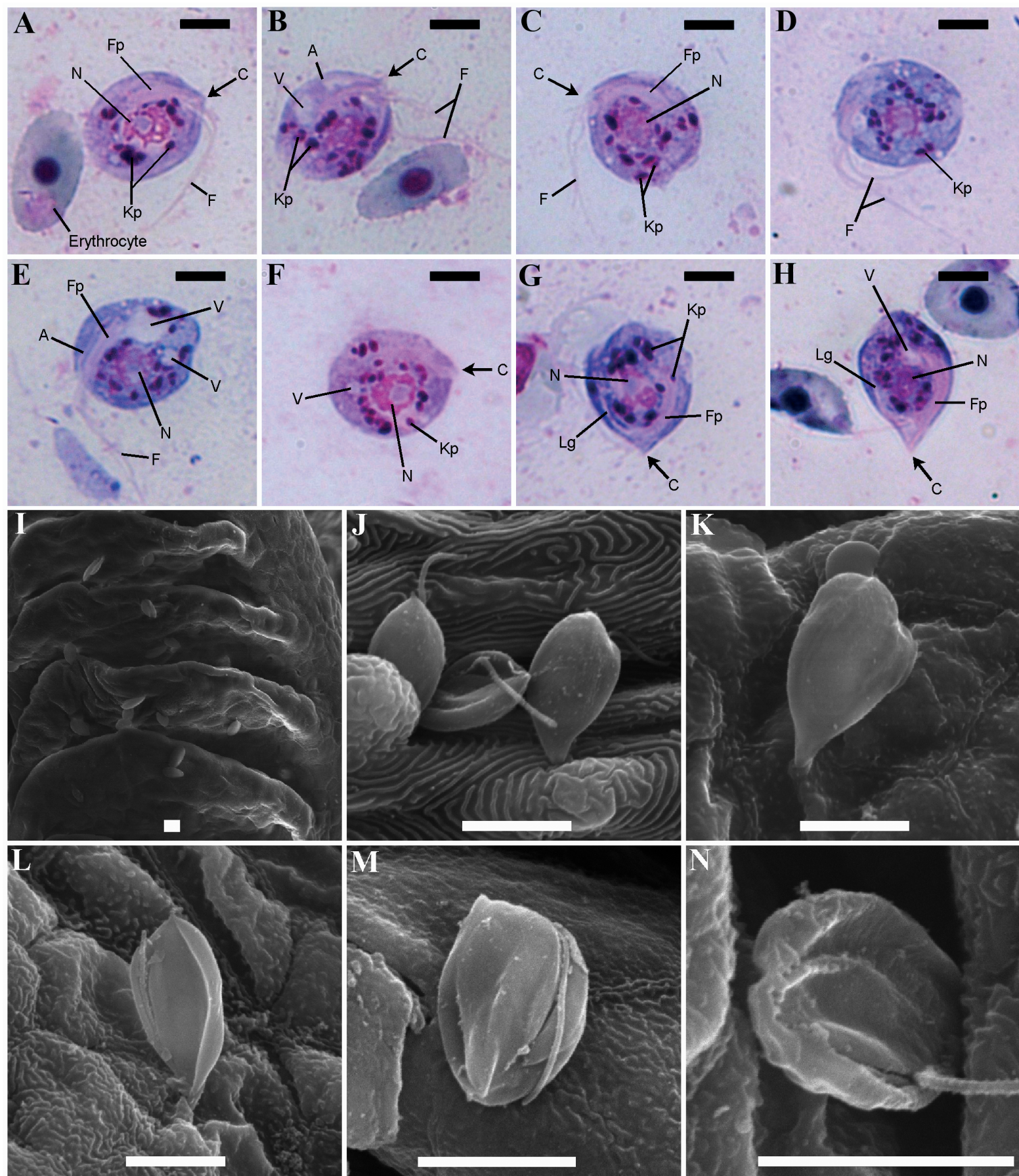
Table 1. Ichthyobodo spp. Measurements of free form from halibut Hippoglossus hippoglossus and salmon Salmo salar. $\mathrm{n}$ : number of cells examined

\begin{tabular}{|c|c|c|c|c|c|c|c|c|c|c|c|}
\hline \multirow[t]{2}{*}{ Measurement } & \multirow[t]{2}{*}{ Code } & \multicolumn{5}{|c|}{ Ichthyobodo sp. (halibut) } & \multicolumn{5}{|c|}{ Ichthyobodo necator (salmon) } \\
\hline & & $\mathrm{n}$ & Mean & $\mathrm{SD}$ & Min. & Max. & $\mathrm{n}$ & Mean & $\mathrm{SD}$ & Min. & Max. \\
\hline Cell length $(\mu \mathrm{m})$ & L1 & 24 & 12.0 & 1.1 & 9.6 & 13.8 & 32 & 11.7 & 1.1 & 8.7 & 13.6 \\
\hline Cell width $(\mu \mathrm{m})$ & L2 & 24 & 11.0 & 0.9 & 9.5 & 13.9 & 32 & 12.9 & 1.4 & 10.3 & 16.0 \\
\hline Cell shape index (L1/L2) & $\mathrm{Ci}$ & 24 & 1.09 & 0.09 & 0.95 & 1.23 & 32 & 0.91 & 0.07 & 0.79 & 1.10 \\
\hline Cell area $\left(\mu m^{2}\right)$ & $\mathrm{Ac}$ & 24 & 103 & 15 & 71 & 144 & 32 & 117 & 22 & 72 & 165 \\
\hline Nucleus area $\left(\mu m^{2}\right)$ & An & 22 & 17 & 3 & 11 & 26 & 31 & 15 & 3 & 10 & 23 \\
\hline Area index (An:Ac) & $\mathrm{Ai}$ & 22 & 0.16 & 0.02 & 0.13 & 0.20 & 31 & 0.13 & 0.02 & 0.10 & 0.17 \\
\hline Position of nucleus at L1 ( $\mu \mathrm{m})$ & N1 & 22 & 5.8 & 0.7 & 4.6 & 7.1 & 32 & 6.4 & 0.7 & 4.8 & 7.7 \\
\hline Position of nucleus at L2 $(\mu \mathrm{m})$ & N2 & 23 & 6.5 & 0.9 & 5.0 & 8.4 & 32 & 7.8 & 0.8 & 5.8 & 9.3 \\
\hline Nucleus position index X (N1/L1) & $\mathrm{Xi}$ & 22 & 0.49 & 0.04 & 0.41 & 0.54 & 32 & 0.55 & 0.03 & 0.46 & 0.60 \\
\hline Nucleus position index Y (N2/L2) & Yi & 23 & 0.59 & 0.06 & 0.45 & 0.69 & 32 & 0.61 & 0.06 & 0.50 & 0.71 \\
\hline Nucleus dimensions at L1 $(\mu \mathrm{m})$ & L3 & 22 & 4.5 & 0.6 & 3.5 & 5.6 & 31 & 4.3 & 0.4 & 3.6 & 5.0 \\
\hline Nucleus dimensions at L2 ( $\mu \mathrm{m})$ & $\mathrm{L} 4$ & 22 & 4.2 & 0.5 & 3.2 & 5.7 & 31 & 3.9 & 0.5 & 3.2 & 4.9 \\
\hline Extent of flagellar pocket at L1 $(\mu \mathrm{m})$ & L5 & 9 & 7.2 & 1.4 & 5.7 & 10.2 & 27 & 4.6 & 0.5 & 3.6 & 5.6 \\
\hline Pocket index (L5/L1) & $\mathrm{Pi}$ & 9 & 0.58 & 0.09 & 0.48 & 0.73 & 27 & 0.40 & 0.06 & 0.29 & 0.51 \\
\hline Number of kinetoplasts & $\mathrm{K}$ & 22 & 16.8 & 5.0 & 6 & 26 & 18 & 70.0 & 21.7 & 44 & 113 \\
\hline
\end{tabular}

Large vacuoles are occasionally observed, one typically near the posterior end of the pocket, another more medial and posterior to the nucleus.

Kinetoplasts occur as densely stained single or clustered dark granules in different sizes (Table 2), the majority in an irregular chain encircling the nucleus (Fig. 3A-F). Counts ranged from 6 to 26 (Table 1).

Attached form (trophozoite). The attached form is pyriform, drawn out towards an attachment area. This area contains the anterior end of the axostyle. The axostyle is located lateral to the flagellar pocket; in stained smears, and these structures together with the longitudinal groove often form a Y-shaped pattern (e.g. Fig. 3G,H). One or 2 larger vacuoles may be visi-

Table 2. Ichthyobodo spp. Measurements $(\mu \mathrm{m})$ of kinetoplasts in cells (free form and trophozoites) from halibut Hippoglossus hippoglossus and salmon Salmo salar. In each studied cell, a 'typical' as well as the smallest (small) and largest (large) single kinetoplast observed were measured (avg. length $\times$ width). n: no. of cells examined

\begin{tabular}{|c|c|c|c|c|c|}
\hline \multirow[t]{2}{*}{ Host } & \multirow[t]{2}{*}{$\mathrm{n}$} & \multirow[t]{2}{*}{ Range } & \multicolumn{3}{|c|}{ Mean size } \\
\hline & & & Small & Typical & Large \\
\hline \multicolumn{6}{|c|}{ Free form } \\
\hline Halibut & 25 & $0.4-2.2 \times 0.3-1.5$ & $0.5 \times 0.4$ & $0.8 \times 0.6$ & $1.6 \times 1.0$ \\
\hline Salmon & 21 & $0.3-1.5 \times 0.2-1.0$ & $0.5 \times 0.3$ & $0.7 \times 0.4$ & $0.9 \times 0.6$ \\
\hline \multicolumn{6}{|c|}{ Trophozoites } \\
\hline Halibut & 12 & $0.3-1.6 \times 0.3-1.2$ & $0.5 \times 0.4$ & $0.9 \times 0.6$ & $1.3 \times 0.9$ \\
\hline Salmon & 7 & $0.4-1.1 \times 0.3-0.9$ & $0.5 \times 0.4$ & $0.7 \times 0.5$ & $0.9 \times 0.6$ \\
\hline
\end{tabular}

ble, located posterior in the cell near the end of the pocket. The kinetoplasts show a similar pattern of distribution and number as the free form (Fig. 3G, $\mathrm{H}$, Tables 2 \& 3).

\section{Ichthyobodo necator from salmon skin (Figs. 4 \& 5)}

Free form. In stained smears, the free form of Ichthyobodo necator is rounded or oval, and typically wider than long (Table 1). In lateral view living cells are flattened and 'comma shaped'. Most cells are biflagellate, with flagellae of unequal length. Occasional quadriflagellate cells are also seen (not measured). We obtained few unambiguous flagellar lengths; the free part of the shorter flagellum measured 6.8 to $14.9(9.7) \mu \mathrm{m}(\mathrm{n}=16)$; the longer part 8.5 to 24.1 (17.9) $\mu \mathrm{m}$ (n $=17$ ). The flagellar pocket is located to the right, and extends less than half of the cell length ( $\mathrm{Pi}$ in Table 1). The positions of the pocket opening and the longitudinal groove are similar to those described for Ichthyobodo sp. from halibut. In stained smears, the axostyle is often prominent, and appears as a bent rod extending along the right cell margin from the anterior cytostomal protrusion to the posterior part of the cell (e.g. Fig. 5C). The

Fig. 3. Ichthyobodo sp. Morphology of cells from gills of halibut Hippoglossus hippoglossus. (A) to (H) Appearance in Diff-Quick stained smears, whereby $(A)$ to $(F)$ show free form and $(G)$ \& $(\mathrm{H})$ parasitic form (trophozoite); (I) to (N) trophozoites. SEM. A: axostyle; C: cytostome; F: flagella; Fp: flagellar pocket; Kp: kinetoplasts; Lg: longitudinal groove; N: nucleus; V: vacuole. Scale bars $=5 \mu \mathrm{m}$ 
Table 3. Ichthyobodo spp. Measurements of attached form of (trophozoites) from halibut Hippoglossus hippoglossus and salmon Salmo salar. n: no. of cells examined

\begin{tabular}{|c|c|c|c|c|c|c|c|c|c|c|c|}
\hline \multirow[t]{2}{*}{ Measurement } & \multirow[t]{2}{*}{ Code } & \multicolumn{5}{|c|}{ Ichthyobodo sp. (halibut) } & \multicolumn{5}{|c|}{ Ichthyobodo necator (salmon) } \\
\hline & & $\mathrm{n}$ & Mean & $\mathrm{SD}$ & Min. & Max. & $\mathrm{n}$ & Mean & $\mathrm{SD}$ & Min. & Max. \\
\hline Cell length $(\mu \mathrm{m})$ & L1 & 27 & 12.8 & 1.2 & 10.9 & 15.8 & 23 & 15.3 & 1.6 & 12.3 & 17.4 \\
\hline Cell width $(\mu \mathrm{m})$ & L2 & 27 & 8.3 & 1.0 & 7.0 & 11.1 & 23 & 8.9 & 1.1 & 6.9 & 10.8 \\
\hline Cell shape index (L1/L2) & $\mathrm{Ci}$ & 27 & 1.57 & 0.17 & 1.24 & 2.02 & 23 & 1.74 & 0.14 & 1.54 & 2.15 \\
\hline Cell area $\left(\mu m^{2}\right)$ & $\mathrm{Ac}$ & 26 & 72 & 13 & 55 & 109 & 23 & 97 & 23 & 60 & 143 \\
\hline Nucleus area $\left(\mu \mathrm{m}^{2}\right)$ & An & 23 & 12 & 3 & 5 & 18 & 23 & 13 & 4 & 6 & 18 \\
\hline Area index (An/Ac) & $\mathrm{Ai}$ & 23 & 0.17 & 0.04 & 0.10 & 0.27 & 23 & 0.13 & 0.02 & 0.10 & 0.16 \\
\hline Position of nucleus at L1 ( $\mu \mathrm{m})$ & N1 & 27 & 5.9 & 0.9 & 4.6 & 7.7 & 23 & 7.6 & 0.8 & 6.2 & 8.8 \\
\hline Position of nucleus at L2 $(\mu \mathrm{m})$ & N2 & 27 & 4.3 & 0.7 & 3.3 & 6.1 & 23 & 5.1 & 0.9 & 3.6 & 6.7 \\
\hline Nucleus position index X (N1/L1) & $\mathrm{Xi}$ & 27 & 0.46 & 0.04 & 0.39 & 0.54 & 23 & 0.50 & 0.05 & 0.43 & 0.62 \\
\hline Nucleus position index Y (N2/L2) & Yi & 27 & 0.52 & 0.05 & 0.45 & 0.63 & 23 & 0.58 & 0.03 & 0.52 & 0.64 \\
\hline Nucleus dimensions at L1 $(\mu \mathrm{m})$ & L3 & 23 & 4.0 & 0.7 & 2.5 & 5.4 & 23 & 4.3 & 0.6 & 3.0 & 5.3 \\
\hline Nucleus dimensions at L2 ( $\mu \mathrm{m})$ & L4 & 23 & 3.6 & 0.5 & 2.6 & 4.7 & 23 & 3.6 & 0.6 & 2.6 & 4.6 \\
\hline Extent of flagellar pocket at L1 $(\mu \mathrm{m})$ & L5 & 21 & 9.5 & 1.0 & 8.2 & 11.5 & 21 & 10.2 & 0.9 & 8.3 & 11.8 \\
\hline Pocket index (L5/L1) & $\mathrm{Pi}$ & 21 & 0.74 & 0.06 & 0.64 & 0.87 & 21 & 0.67 & 0.08 & 0.53 & 0.82 \\
\hline Number of kinetoplasts & $\mathrm{K}$ & 12 & 19.8 & 9.3 & 7 & 34 & 8 & 59.1 & 14.4 & 40 & 87 \\
\hline
\end{tabular}

A

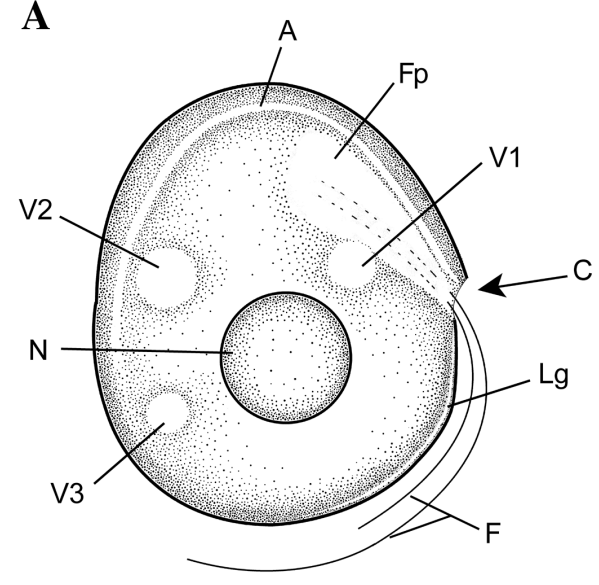

B

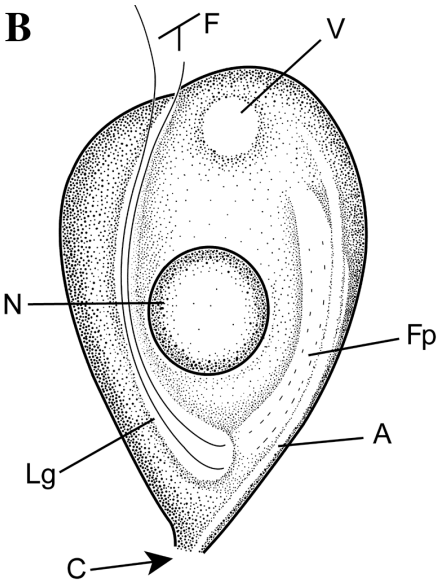

Fig. 4. Ichthyobodo necator. Characteristic structure. Kinetoplasts not drawn. (A) Free

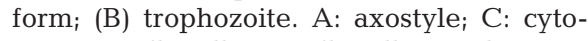
stome; F: flagella; Fp: flagellar pocket; Lg: longitudinal groove; N: nucleus; V: vacuole nucleus is rounded or oval in shape and centrally located. Its area constitutes ca. 1/8th of the cell area (Table1). A vacuole (V1) is sometimes evident in the area between the nucleus and the flagellar pocket (Fig. $4 \mathrm{~A})$. In addition, 1 or 2 vacuoles occur posterior in the cell (V2 and V3, Fig. 4A). The most prominent (V2) is located near the end of the axostyle, while the smaller (V3) occasionally occurs in the area near the end of the longitudinal groove. Many small kinetoplasts occur as densely stained, regularly sized, oval spots in DiffQuick $^{\mathrm{TM}}$ stained smears. No regular pattern in their distribution in the cell was detected, but they are rarer in the pocket-groove region (Fig. 5A-E). Counts of kinetoplasts in images range from 44 to 113 (Table 1).

Attached form (trophozoite). The attached form of Ichthyobodo necator $(\mathrm{n}=23,15.3 \pm 1.6 \times 8.9 \pm 1.1 \mu \mathrm{m})$ shows a pyriform shape similar to that of Ichthyobodo sp. from halibut. As in Ichthyobodo sp. from halibut, the axostyle, flagellar pocket and longitudinal groove appear as a Y-shaped pattern in the cell. The flagellae of trophozoites can be difficult to detect in both fresh preparations and in stained smears, but in SEM images (Fig. 5M) 2 unequal flagellae are visible. In trophozoites a single large vacuole is occasionally seen located near the posterior end of the flagellar pocket and the axostyle (Fig. 4B). The kinetoplasts (Fig. 5F,G, Tables 2 \& 3) are similar in pattern and number to the free form.

\section{Comparison of Ichthyobodo sp. from halibut with I. necator}

Free form. We found no significant differences in the cell lengths (L1) of the free forms, but Ichthyobodo necator was significantly wider (L2) than Ichthyobodo sp. $(t=-5.7, \mathrm{p}<0.001, \mathrm{df}=54)$. Consequently the cell shapes of Ichthyobodo sp. and I. necator was different 

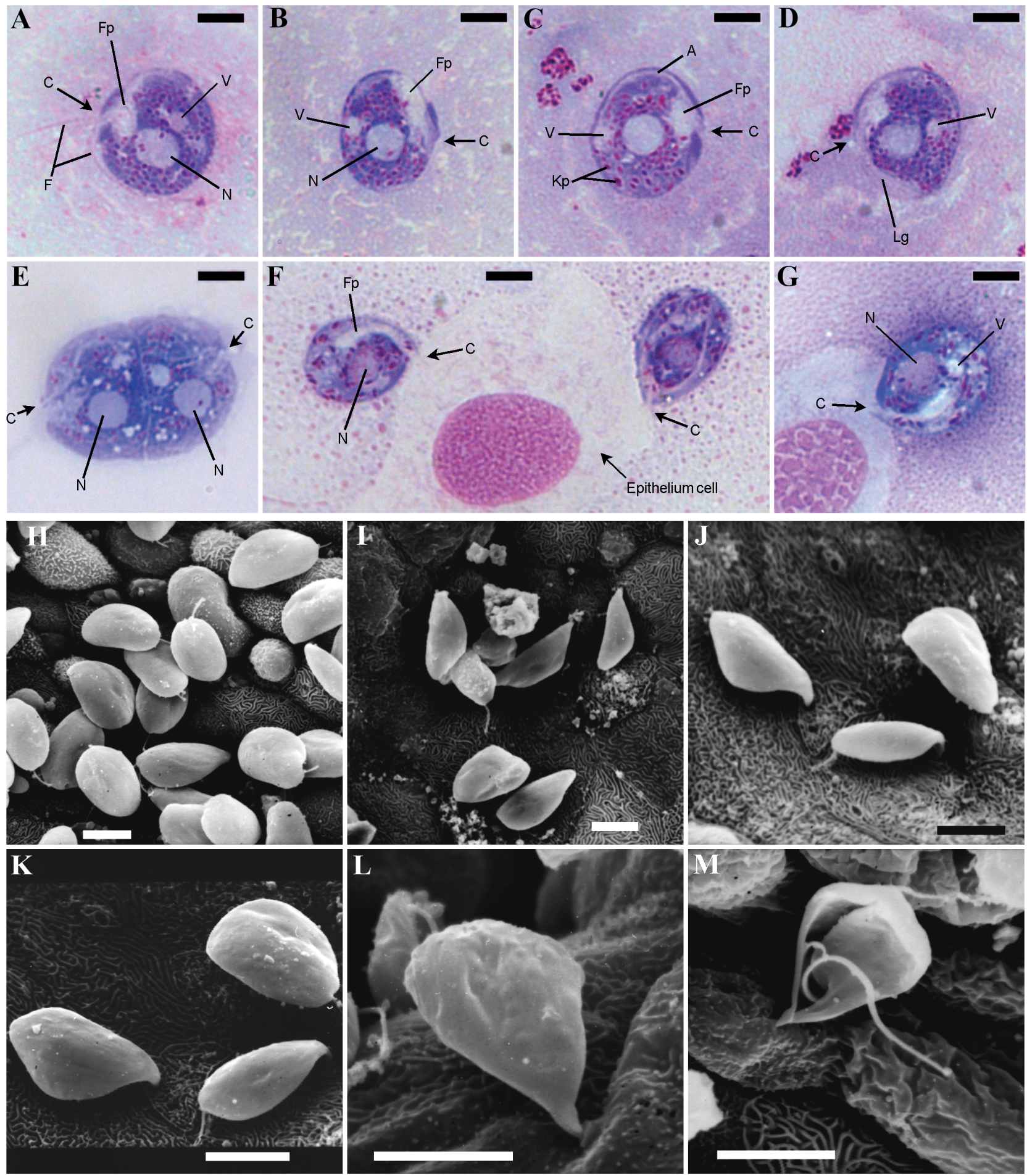

Fig. 5. Ichthyobodo necator. Morphology of cells from skin of juvenile salmon Salmo salar. (A) to (G) Appearance in Diff-Quick stained smears, whereby (A)-(D) show free form: (E) dividing form, and (F) \& (G) parasitic form (trophozoite); (H) to (M) trophozoites. SEM. A: axostyle; C: cytostome; F: flagella; Fp: flagellar pocket; Kp: kinetoplasts; Lg: longitudinal groove; $\mathrm{N}$ : nucleus; V: vacuole. Scale bars $=5 \mu \mathrm{m}$

in stained smears, the halibut flagellate being elongate along the L1 axis (cell shape index, $\mathrm{Ci}>1$ ), while $I$. necator tended to be transversely oval $(\mathrm{Ci}<1)$
(Table 1). This is also reflected in statistically significant differences in their shape parameters $(\mathrm{Ci}=$ length/width) $(\mathrm{df}=54, t=8.1, \mathrm{p}<0.001)$. 


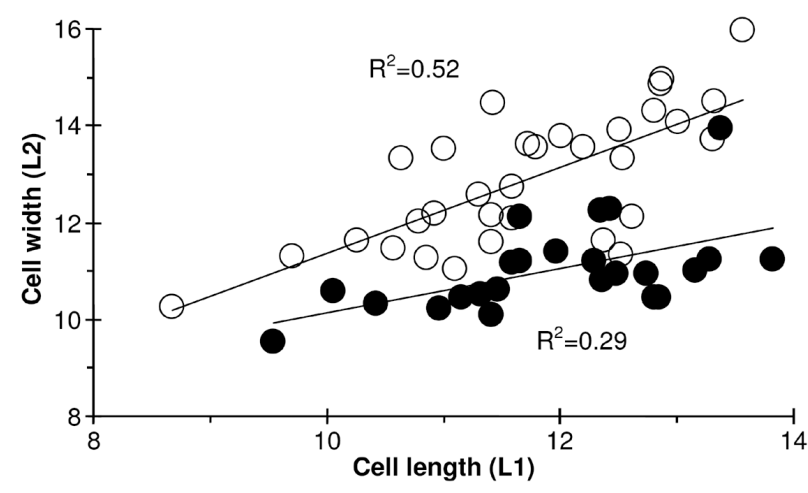

Fig. 6. Ichthyobodo sp. Cell shape of free forms of cells from $(\bullet)$ halibut and $(O)$ salmon parr. Least-squares trend lines and corresponding $\mathrm{R}^{2}$ values indicated

We found statistically significantly positive correlations between length and width of both Ichthyobodo sp. ( $\left.\mathrm{n}=24, \mathrm{R}_{\mathrm{S}}=0.57, \mathrm{p}=0.004\right)$ and I. necator $(\mathrm{n}=32$, $\left.\mathrm{R}_{\mathrm{S}}=0.72, \mathrm{p}<0.001\right)$, but the cell shape appears to be less affected by cell growth in $I$. necator (Fig. 6). The extent of the flagellar pocket along the length axis (Pi in Table 1) in Ichthyobodo sp. reach more posterior than in $I$. necator $(t=7.0, \mathrm{p}<0.001 \mathrm{df}=34)$. We found a small (49\% vs. $55 \%$ of L1, see Table 1) but statistically significant difference in the relative position of the nucleus in the cell $(\mathrm{N} 1 / \mathrm{L} 1 ; t=-6.6, \mathrm{p}<0.001 \mathrm{df}=$ 52,). Fig. 7 illustrates the position of the nucleus relative to the extent of the flagellar pocket; the latter contributing most to distinguishing between the 2 Ichthyobodo forms. There are fewer kinetoplasts in Ichthyobodo sp. from halibut than in I. necator (Tables 1 \& 3). The number of kinetoplasts in $I$. necator increases with increasing cell size $\left(\mathrm{R}_{\mathrm{S}}=0.83, \mathrm{p}<0.001\right.$ $\mathrm{n}=18$,), while in the halibut flagellate the counts did not correlate significantly with size $\left(\mathrm{R}_{\mathrm{S}}=0.40, \mathrm{~ns}, \mathrm{n}=\right.$ 22) (Fig. 8).

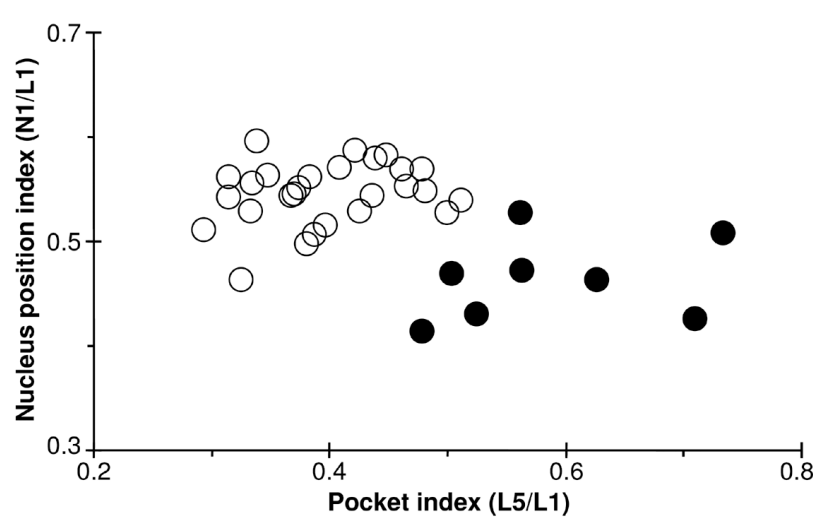

Fig. 7. Ichthyobodo spp. Morphometrics of free forms of (๑) Ichthyobodo sp. from halibut and (O) I. necator from salmon parr, showing position of nucleus (N1) in relation extent of flagellar pocket (L5) (both in relation to L1)

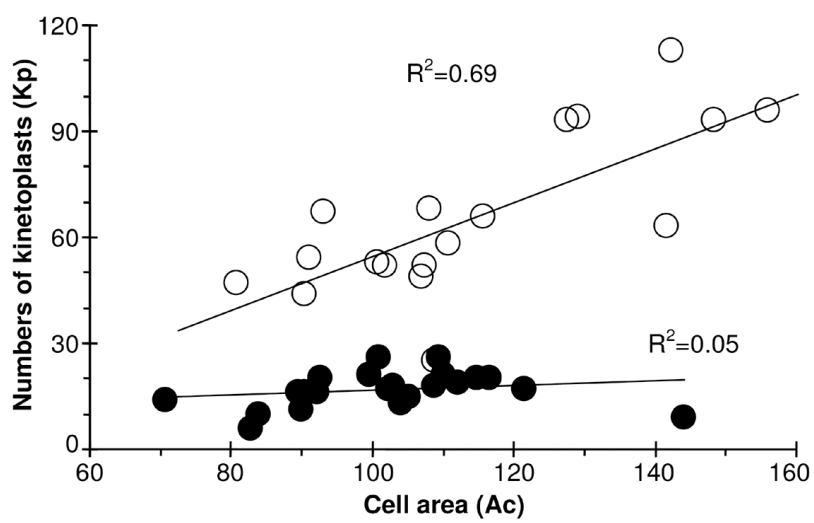

Fig. 8. Ichthyobodo spp. Comparisons of free forms of (O) Ichthyobodo sp. from halibut and (O) I. necator from salmon parr, showing number of kinetoplasts as a function of cell area $\left(\mu \mathrm{m}^{2}\right)$

Attached form (trophozoite). As opposed to the free forms, the cell shape index ( $\mathrm{Ci}$, Table 3$)$ of Ichthyobodo sp. trophozoites is less elongate than that of Ichthyododo necator $\left(\mathrm{Ci}_{;} \mathrm{df}=48, t=-3.8, \mathrm{p}<0.001\right)$. The halibut form is also smaller (length L1; df $=48, t=-6.3, \mathrm{p}<0.001$, width $\mathrm{L} 2 ; \mathrm{df}=48, t=-2.0, \mathrm{p}=0.04)$. Width increases with increasing length in both species, in a similar pattern. We found differences between the 2 flagellates in both nucleus index (N1/L1; $\mathrm{df}=48, t=-3.5, \mathrm{p}=0.001)$ and pocket index (L5/L1; $\mathrm{df}=40, t=3.4, \mathrm{p}=0.002)$, but they are not clearly separated by these parameters (Fig. 9).

\section{Ssu sequences}

Sequences obtained from the 4 Ichthyobodo sp. samples from halibut (1854 nt) were identical. The single partial ssu rDNA sequence (DQ414520) showed highest similarity to sequences from another Ichthyobodo

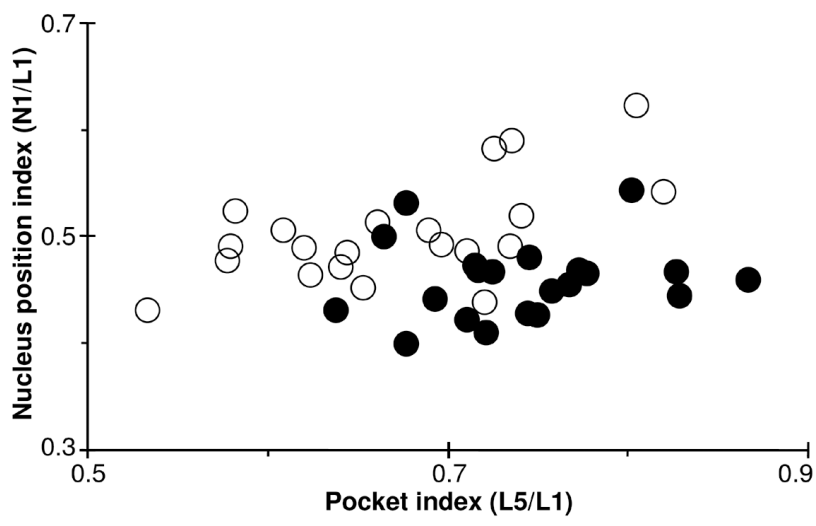

Fig. 9. Ichthyobodo spp. Morphometrics of trophozoites from (@) juvenile halibut and (O) salmon parr, showing position of nucleus (N1) and extent of flagellar pocket (L5) in relation to cell length (L1) 


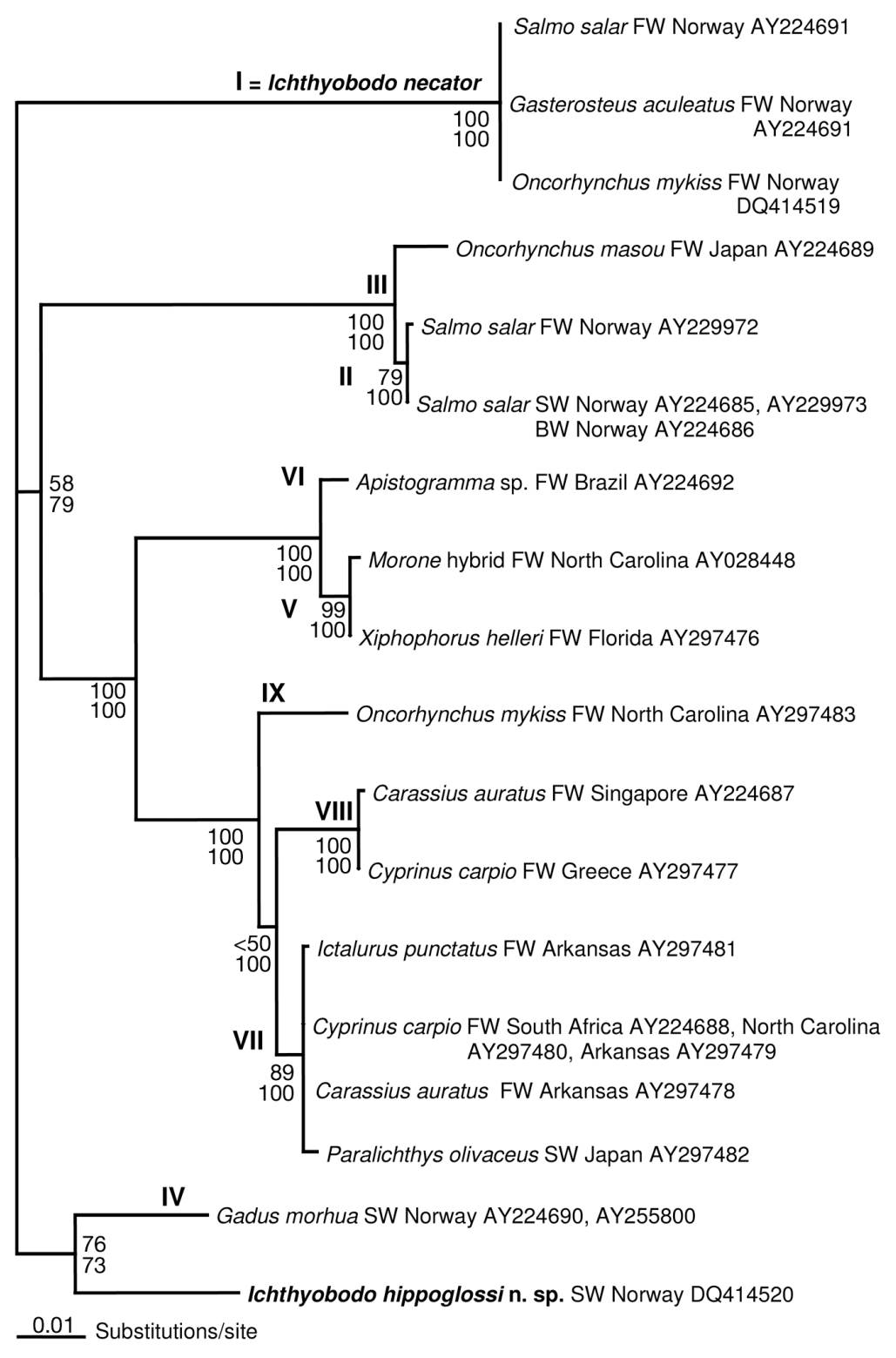

Fig. 10. Ichthyobodo spp. Unrooted maximum likelihood tree with relative branch lengths, based on alignment of ssu rDNA sequences from cells with 1491 characters, constructed using PAUP 4.0b10. Ichthyobodo sp. indicated by host, environment, locality and GenBank accession numbers. FW: freshwater; BW: brackish water; SW: seawater. Support values are given at nodes: upper values $=$ ML bootstrap (PAUP), lower values = quartet puzzling (TREEPUZZLE). Species/strain designations (after Todal et al. 2004 and Callahan et al. 2005) indicated by roman numerals

species isolated from the marine fish Gadus morhua (96.2\%, 1790/1861, 10 indels). The similarity between Ichthyobodo sp. from halibut and I. necator was $93.5 \%$ (AY224691) (1744/1866, 12 indels).

The relationship to the other available partial ssu rDNA sequences from Ichthyobodo spp. is shown in an unrooted maximum likelihood tree in Fig. 10.

\section{DISCUSSION}

In recent reviews, the genus Ichthyobodo has been considered to contain a single valid species, I. necator. Two other species, Tetramitus nitschei Weltner, 1894 and Costia pyriformis Davis, 1943, have been considered as belonging to the genus Ichthyobodo (Robertson 1985, Todal et al. 2004). However, the description of the former is so inadequate that it can never be recognised with certainty (Todal et al. 2004), and C. pyriformis shows features suggesting that it may be a bodonid or cryptobiid, rather than belonging in the genus Ichthyobodo.

The morphological variation of Ichthyobodo necator indicated in the literature is large, but in the light of recent molecular evidence, it now appears clear that the different descriptions were based on different Ichthyobodo species. A delimitation of $I$. necator to the species described by Henneguy $(1883,1884)$ is therefore much needed, and may allow recognition of morphological characters aiding the separation of species detected by molecular work.

At present, from molecular studies, 2 species of Ichthyobodo appear to infect salmonids in Europe: Ichthyobodo spp. I and II of Todal et al. (2004). Elsewhere, a species or strain (III) infects Oncorhynchus masou in Japan, and Callahan et al. (2005) presented evidence for an additional species (Species IX) infecting rainbow trout Oncorhynchus mykiss in the USA. Since I. necator is a species infecting European salmonids, we are cautious as regards records and descriptions from other parts of the world. Species I of Todal et al. (2004) predominantly infects the skin of the fish, but also may occur in moderate numbers on the gills. It is thus far only known from freshwater. Species II is a typical gill parasite, occurring in fresh-, brackish and seawater (Todal et al. 2004). Bruno (1992) showed that Ichthyobodo spp. trophozoites in the gills of 3 species of Scottish salmonids reared in freshwater averaged 9.0 to $10.2 \mu \mathrm{m}$ in length, while trophozoites from seawater reared Atlantic salmon were significantly smaller, averaging 5.5 to $6.9 \mu \mathrm{m}$ in length. He concluded that a smaller marine species exists that may infect salmon reared in the marine environment. The 2 species of Bruno (1992) may well represent the Ichthyobodo spp. I and II of Todal et al. (2004), and the larger freshwater 
form is the most likely to represent $I$. necator Henneguy, 1883 since Henneguy $(1883,1884)$ described I. necator from the epidermis of trout fry in France as a quite large form $(0.02 \times 0.01 \mathrm{~mm})$. Morphological redescription and molecular characterisation of $I$. necator in the strictest sense, from the type host Salmo trutta from the type locality (Paris area, France) is needed. However, we identify the form (Species I) found by us on the skin, fins and gills of salmon reared in freshwater in Norway as I. necator for the following reasons: (1) freshwater habitat, (2) salmonid host, (3) skin and fins as major sites, (4) size, (5) pathogenicity to juvenile Salmo spp. in hatcheries. The other characteristics described by Henneguy (1883, 1884) are of little use, and some of his interpretations were clearly wrong (e.g. 3 flagellae).

Ichthyobodo sp. from halibut is separated from $I$. necator from salmon by its shape in air dried stained smears, by its low number of variably sized kinetoplasts and by a longer flagellar pocket. There is also a clear increase in the number of kinetoplasts in $I$. necator with increasing cell size (area), a pattern absent from Ichthyobodo sp. from halibut.

The 2 forms are also clearly separated by their ssu rDNA sequences; alignments of partial ssu sequences showed $93.5 \%$ similarity. Consequently, Ichthyobodo sp. from halibut is considered a new species.

The revised classification of the Kinetoplatea with an erection of the new subclass Prokinetoplastina Vickerman, 2004 and the order Prokinetoplastida Vickerman, 2004 for Ichthyobodo and Perkinsiella (Moreira et al. 2004) necessitates the erection of the new family Ichthyobodonidae for the genus Ichthyobodo.

\section{Taxonomic summary}

- Class Kinetoplastea Honigberg, 1963.

- Order Prokinetoplastina Vickerman, 2004.

- Family Ichthyobodonidae fam. nov.

- Diagnosis: polykinetoplastic, biflagellate, flagellae originate in pocket, continuing as a furrow. Cytostome extends into a long microtubule supported cytostomeal canal. Ectoparasitic, freshwater and marine.

- Single genus, Ichthyobodo Pinto, 1928.

- Ichthyobodo hippoglossi n. sp.

- Etymology: after the type host.

- Type host: Atlantic halibut Hippoglossus hippoglossus (L.) (cultured fry).

- Type locality: Romsdalsfjorden, south of Otrøy, Norway.

- Site: gills and skin.

- ssu rDNA sequence: DQ414520.

- Type material: syntype slide deposited in the Zoological Museum, University of Bergen, designated ZMBN 77812.
Based on our experience with the 2 described species, we outline a system for standardisation of the measurements of Ichthyobodo cells, in particular the free form. The intention is to enable the morphological separation of Ichthyobodo spp. recognised by other means, such as ssu rDNA sequencing.

There appears to be a controversy in the literature regarding the structure of Ichthyobodo cells. In I. necator and I. hippoglossi n. sp. we found the pocket on the right side of the cell and consequently the furrow on the left, in agreement with the interpretation of some early researchers (Andai 1933, Benisch 1936). However, the furrow has also been reported as being located on the right side (Joyon \& Lom 1969, Lom \& Dyková 1992). SEM pictures of Ichthyobodo spp. from various hosts either show the furrow positioned on the left side (Robertson 1985, his Fig. 1.5; Urawa \& Kusakari 1990, their Fig. 8; Forsythe et al. 1991, their Fig. 1b), or the appearance of the flagellum suggests it leaves a furrow on the left side (Urawa \& Kusakari 1990, their Figs. 5 \& 6; Urawa 1992, his Figs. 10 \& 11; Beck et al. 1996, their Fig. 2). In contrast, Urawa et al. (1998, their Fig. 4) depicted a specimen with the furrow apparently on the right. These observations suggest either that some interpretations are erroneous or that symmetry varies within or between species. We suggest that this aspect be carefully addressed in future studies.

In the light of recent evidence for the existence of several Ichthyobodo spp., the observations by Bruno (1992) suggest that the size of Ichthyobodo cells may be a valuable character. However, since measurements from attached trophozoites in sections offer practically no other morphological information, we here advocate examination of the free form in stained smears. As we have shown, the shape of different species in such smears may differ. The axostyle, a rod like structure lateral to the flagellar pocket that enters the anterior cell protrusion and the attachment disc probably represent the cytostome canal observed in ultrastructural studies (Joyon \& Lom 1966, 1969, Miyazaki et al. 1986). Quadriflagellate cells are generally believed to be pre-division stages, hence their frequency is likely to be high in proliferating infections. Previous studies agree that the 2 principal flagellae are of unequal length, but there is so far no indication that flagellar length may be a useful distinguishing character. Vacuoles are often noted in I. 'necator' from freshwater hosts (Benisch 1936, Fish 1940, Tavolga \& Nigrelli 1947), and ultrastructural studies on Ichthyobodo sp. trophozoites from cyprinids suggest that a contractile vacuole occurs lateral to the nucleus in close contact with the flagellar pocket (Joyon \& Lom 1966, 1969). A vacuole occasionally seen at the posterior end of the axostyle (present study) could be a digestive vacuole formed at the end of the cytostomeal 
canal. Diamant (1987) studied a marine Ichthyobodo sp. from dab Limanda limanda (L.) and found no evidence for a contractile vacuole, while Urawa \& Kusakari (1990) did observe contractile vacuoles in Ichthyobodo sp. from Oncorhynchus keta transferred to seawater, albeit fewer than those seen in freshwater. Ultrastructural verification of a vacuole homologous to that described by Joyon \& Lom $(1966,1969)$ is still lacking.

There are several records of Ichthyobodo sp. infections in marine hosts (see Urawa et al. 1998). Some of these are from pleuronectid flatfish related to halibut, and may represent I. hippoglossi n. sp. At present, we know little about the host specificity of marine Ichthyobodo spp., except that Atlantic cod appears to be attacked by a species distinct from I. hippoglossi. I. necator (sensu novo) have been found to parasitise salmon, wild brown trout and rainbow trout, as well as threespined sticklebacks in Norway. Several species (I, V, VII) have been found to parasitise unrelated hosts (Todal et al. 2004, Callahan et al. 2005), and an exceptional finding is Ichthyobodo sp. VII, (common on North American cyprinids and catfish in freshwaters) on a Japanese marine flatfish (Callahan et al. 2005).

The separation of Ichthyobodo hippoglossi n. sp. from $I$. necator is fairly straightforward, due to clear differences in environment, host and the presence of distinguishing characters. However, we consider it likely that the actual number of Ichthyobodo spp. worldwide is very high, not least in marine environments. Since the numbers of identifying characters are limited, at least at the light microscope level, it appears likely that 'cryptic' species will be discovered without apomorphic traits.

\section{LITERATURE CITED}

Andai G (1933) Über Costia necatrix. Arch Protistenkd 79: 283-297

Beck K, Lewbart G, Piner G (1996) The occurrence of an Ichthyobodo-like organism on captive Atlantic spadefish, Chaetodipterus faber (Broussonet). J Fish Dis 19:111-112

Benisch J (1936) Untersuchungen über Costia necatrix Leclerq. Z Fisch Hilfswiss 34:755-770

Bergh O, Nilsen F, Samuelsen OB (2001) Diseases, prophylaxis and treatment of the Atlantic halibut Hippoglossus hippoglossus: a review. Dis Aquat Org 48:57-74

Bruno DW (1992) Ichthyobodo sp. on farmed Atlantic salmon, Salmo salar L., reared in the marine environment. J Fish Dis 15:349-351

Callahan HA, Litaker RW, Noga EJ (2005) Genetic relationships among members of the Ichthyobodo necator complex: implications for the management of aquaculture stocks. J Fish Dis 28:111-118

Diamant A (1987) Ultrastructure and pathogenesis of Ichthy-

Editorial responsibility: Dieter Steinhagen,

Hannover, Germany obodo sp. from wild common dab, Limanda limanda L., in the North Sea. J Fish Dis 10:241-247

Fish FF (1940) Notes on Costia necatrix. Trans Am Fish Soc 70:441-445

Forsythe JW, Hanlon RT, Bullis RA, Noga EJ (1991) Octopus bimaculoides (Pickford \& McConnaughey, 1949): a marine invertebrate host for ectoparasitic protozoans. J Fish Dis 14:431-442

Henneguy LF (1883) Sur un infusoire flagellé, ectoparasite des poissons. C R Hebd Séances Acad Sci 96:658-660

Henneguy LF (1884) Sur un infusoire flagellé ectoparasite de la truite. Arch Zool Exp Gén Sér 2 2:403-411

Joyon L, Lom J (1966) Sur l'ultrastructure de Costia necatrix Leclerq (zooflagellé); place systématique de ce Protiste. C R Hebd Séances Acad Sci Ser D 262:660-663

Joyon L, Lom J (1969) Etude cytologique, systématique et pathologique d'Ichthyobodo necator (Henneguy, 1883) Pinto, 1928 (zooflagelle). J Protozool 16:703-719

Lom J, Dyková I (1992) Protozoan parasites of fishes. Developments in aquaculture and fisheries science, Vol 26, Elsevier, Amsterdam

Miyazaki T, Rogers WA, Plumb JA (1986) Histopathological studies on parasitic protozoan diseases of the channel catfish in the United States. Bull Fac Fish Mie Univ 1(13):1-9

Moreira D, Lopez-Garcia P, Vickerman K (2004) An updated view of kinetoplastid phylogeny using environmental sequences and a closer outgroup: proposal for a new classification of the class Kinetoplastea. Int J Syst Evol Microbiol 54:1861-1875

Page RDM (1996) TREEVIEW: an application to display phylogenetic trees on personal computers. Comput Appl Biosci 12:357-358

Posada D, Crandall KA (1998) Modeltest: testing the model of DNA substitution. Bioinformatics 14:817-818

Robertson DA (1985) A review of Ichthyobodo necator (Henneguy, 1883), an important and damaging fish parasite. Recent Adv Aquac 2:1-30

Rødseth OM (1995) Sykdommer, parasitter og vaksiner. In: Pittman K, Kjørrefjord AG, Berg L, Engelsen R (eds) Kveite - fra forskning til næring. Kystnæringen Forlag og Informasjonskontor, Bergen, p 61-94

Swofford DL (2000) PAUP*, phylogenetic analysis using parsimony ("and other methods), Version 4, Sinauer Associates, Sunderland, MA

Tavolga WN, Nigrelli RF (1947) Studies on Costia necatrix (Henneguy). Trans Am Microsc Soc 66:366-378

Todal JA, Karlsbakk E, Isaksen TE, Plarre H and 5 others (2004) Ichthyobodo necator (Kinetoplastida) - a complex of sibling species. Dis Aquat Org 58:9-16

Urawa S (1992) Epidermal responses of chum salmon (Oncorhynchus keta) fry to the ectoparasitic flagellate Ichthyobodo necator. Can J Zool 70:1567-1575

Urawa S, Kusakari M (1990) The survivability of the ectoparasitic flagellate Ichthyobodo necator on chum salmon fry (Oncorhynchus keta) in seawater and comparison to Ichthyobodo sp. on Japanese flounder (Paralichthys olivaceus). J Parasitol 76:33-40

Urawa S, Ueki N, Nakai T, Yamasaki H (1991) High mortality of cultured juvenile Japanese flounder, Paralichthys olivaceus (Temminck \& Schlegel), caused by the parasitic flagellate Ichthyobodo sp. J Fish Dis 14:489-494

Urawa S, Ueki N, Karlsbakk E (1998) A review of Ichthyobodo infection in marine fishes. Fish Pathol 33:311-320

Submitted: February 24, 2006; Accepted: September 20, 2006 Proofs received from author(s): December 20, 2006 